\title{
Challenges in Marine Restoration Ecology: How Techniques, Assessment Metrics, and Ecosystem Valuation Can Lead to Improved Restoration Success
}

\author{
Laura Basconi, Charles Cadier, \\ and Gustavo Guerrero-Limón
}

\begin{abstract}
Evaluating the effectiveness and success of coastal marine habitat restoration is often highly challenging and can vary substantially between different habitat types. The current article presents a state-of-the-art review of habitatlevel restoration in the coastal marine environment. It sets out most successful techniques across habitats and suggestions of better metrics to assess their success. Improvements in restoration approach are outlined, with a particular focus on selective breeding, using recent advancements in genetics. Furthermore, the assessment of ecosystem services, as a metric to determine restoration success on a spatiotemporal scale, is addressed in this article. As the concept of ecosystem services is more tangible for a nonscientific audience, evaluating restoration success in this manner has the potential to greatly contribute to raising awareness of environmental issues and to implement socioeconomic policies. Moreover, habitatbased restoration has been proven to be an effective tool to address the issue of ecosystem service sustainability and poverty alleviation. Appropriate conservation management, prior to the implementation of restoration activities, is crucial to create an environment in which restoration efforts are likely to succeed.
\end{abstract}

The authors Laura Basconi, Charles Cadier and Gustavo GuerreroLimón have been equally contributing to this chapter.

L. Basconi $(\bowtie)$

Ca Foscari University, Venice, Italy

e-mail:956409@stud.unive.it

C. Cadier $(\bowtie)$

MER Consortium, UPV, Bilbao, Spain

e-mail: c.cadier@griffith.edu.au

G. Guerrero-Limón $(\bowtie)$

MER Consortium, UPV, Bilbao, Spain

University of Liege, Ulg, Belgium

e-mail: g.guerrero@doct.uliege.be

\subsection{Introduction}

Restoration ecology is an emerging branch of environmental science which gained increased attention since the 1990s. The Society of Ecological Restoration, founded in 1983, states that ecological restoration is an intentional activity which has been initiated to accelerate the recovery of an ecosystem with respect to its health, integrity, and sustainability (SER 1998; Bullock et al. 2011). Frequently, the ecosystem that requires restoration has been degraded, damaged, transformed, or entirely destroyed as the direct or indirect result of human activities. Restoration ecology has the aim to restore the integrity of ecological systems, therefore restoring a critical range of variability in biodiversity, ecological processes and structures, regional and historical context, and sustainable cultural practices (SER 1998). In the last 20 years, restoration actions have been increasingly carried out all over the world (Swan et al. 2016; Zhang et al. 2018), and it is anticipated to become one of the most important fields within conservation science of the twenty-first century (Hobbs and Harris 2001).

At present, passive conservation aims to protect coastal marine habitats by removing or mitigating environmental stressors (e.g., removing polluting agents, increase water quality, and/or ban human uses at the damaged coastal site). Although these direct and indirect anthropogenic stressors once removed could allow for the natural recovery of these systems, in reality this does not always occur (Perrow and Davy 2002; Cox et al. 2017). For instance, in the case of seagrasses, even if there is an improvement in water quality and/ or coastal tourism is banned, there could no longer be a population which can produce seeds nearby the damaged site. It impedes the natural recovery of the lost habitat (Nyström et al. 2012). In these conditions, restoration can help conservationists to reach their goal. Active conservation or restoration is the practice of rebuilding degraded, damaged, or destroyed ecosystems and habitats by active human intervention (Hobbs and Norton 1996; Palmer et al. 1997; Elliott 
et al. 2007). The implementation of appropriate conservation management, prior to any restoration attempt, is vital to reduce impacts making restoration feasible (Hobbs and Norton 1996; Benayas et al. 2009; McDonald et al. 2016).

Increased interest is not the result of scientific enthusiasm over a new research topic, but it is rather due to the urgent need to counteract the alarming decline in the cover of important habitats. Coastal marine ecosystems are being lost at alarming rates, and for them, passive protection could not be enough (Pandolfi et al. 2003; Hoekstra et al. 2005; Abelson et al. 2015; Doxa et al. 2017). Seagrass beds, mangroves, salt marshes, corals, and oyster reefs are important nursery habitats for species of economic interest (Robertson and Duke 1987; Hemminga and Duarte 2000). Active filtration in oyster reefs and sediment settlement facilitation in salt marshes, mangroves, and seagrass beds contribute to water purification (McLeod et al. 2011; Grabowsky et al. 2012). Moreover, salt marshes, mangroves, seagrass beds, macroalgal forests, corals, and oyster reefs are natural barriers against hydrodynamic forces and thus stabilize sediments (Moberg and Folke 1999; Hemminga and Duarte 2000; Lovelock et al. 2005; Gedan et al. 2011). Those habitats prevent coastal erosion (Callaway et al. 1997; Herkül and Kotta 2009). This sediment accumulation ultimately leads to the creation of organic-rich soils, acting as a carbon storage (blue carbon) and therefore a buffer against global warming (Nelleman et al. 2009; McLeod et al. 2011). Furthermore, leisure and recreational services are provided by coral reefs, for instance, generating scuba diving tourism which produces revenues to local communities (Moberg and Folke 1999). Some of these ecosystems also act as sites of social and cultural heritage such as sacred mangrove forests (Rönnbäck et al. 2007). The multitude of services and benefits derived from these coastal marine habitats highlight the need to restore them to have long-lasting ecosystem services provisioning.

Since the dawn of the industrial revolution, mankind has been inducing major changes at a global scale, being the primary cause of global warming. Humankind exploited nature lacking the consciousness of the long-term consequences. This unprecedented use brought to present enormous challenges to protect the environment. Ecosystem deterioration and loss of many important coastal habitats is one of the many repercussions of the multiple stresses that humans have caused over the past decades (Halpern et al. 2008; Waycott et al. 2009; Micheli et al. 2013). Cumulative impacts, such as overfishing, oil drilling, maritime transport, and coastal tourism, affect coastal marine habitats worldwide, leading to strong pressures to pristine environments, ultimately resulting in habitat loss (Airoldi and Beck 2007; Abelson et al. 2015; Doxa et al. 2017). Human activities have globally transformed or destroyed 30 to $50 \%$ of mangroves (Valiela et al. 2001; Duke et al. 2007; Giri et al. 2011;
Richards and Friess 2017); 40\% of global coral reefs, with a shocking prevision of almost complete disappearance by 2050 (Pandolfi et al. 2003; Eyre et al. 2018); 29\% of seagrass beds (Waycott et al. 2009); and 85\% of oyster reefs (Lotze et al. 2006; Beck et al. 2011). A comparable loss has been observed for macroalgal forests that, together with seagrass loss, has been considered a real "marine deforestation" (Airoldi and Beck 2007; Connell et al. 2008; Yu et al. 2012). Consequently, the decline of marine forests is leading to a reduction of structurally complex habitats, especially across temperate marine environments (Scheffer et al. 2001; Steneck et al. 2002; Sala 2004) with a significant reduction in species abundance and relative distributions (Novacek and Cleland 2001; Worm et al. 2006; Airoldi et al. 2008).

To counteract this loss, the most used mitigation action is the establishment of marine protected areas (MPAs). While recently O'Leary et al. (2017) stated that climate disturbance does not affect natural recovery, sea surface temperature (SST) increase and acidification due to climate change can present challenges for coastal marine habitat passively conserved (Harley et al. 2006; Hoegh-Guldberg and Bruno 2010). Furthermore, the stage of habitat degradation is often so pervasive that habitats require assisted recovery as well as active restoration (Young 2000; Perkol-Finkel and Airoldi 2010). Ecological restoration at the sea is, however, in its infancy, sometimes resulting in unsuccessful restoration attempts (Bayraktarov et al. 2016).

This paper aims to present marine restoration challenges through a review of published peer-reviewed studies with three main approaches: (i) habitat-based restoration techniques, (ii) restoration success among habitats and the importance of assessment metrics, and (iii) the importance of ecosystem service valuation.

\subsection{Habitat-Level Restoration}

Habitat restoration is an emerging field in marine ecology. A search on Google Scholar using the search terms "marine," "restoration," and "ecology" ended up with 191,000 articles displayed in the graph below (Fig. 5.1). Interest in marine restoration ecology worldwide arose in the 1990s, but just in the last 20 years, restoration actions have been increasingly carried out all over the world (a trend clearly identified also by Swan et al. (2016) and Zhang et al. (2018)).

Even though ecological restoration of marine ecosystems is quite young, some guidelines and rules have been identified, for instance, the need to define the historical baseline to which the system will be restored, prior to any restoration attempt (Seaman 2007). This has to be in a manner that restoration will be carried out in areas in which the species aimed to be restored was present before the disturbance. Moreover, the introduction of a species, such as a habitat 


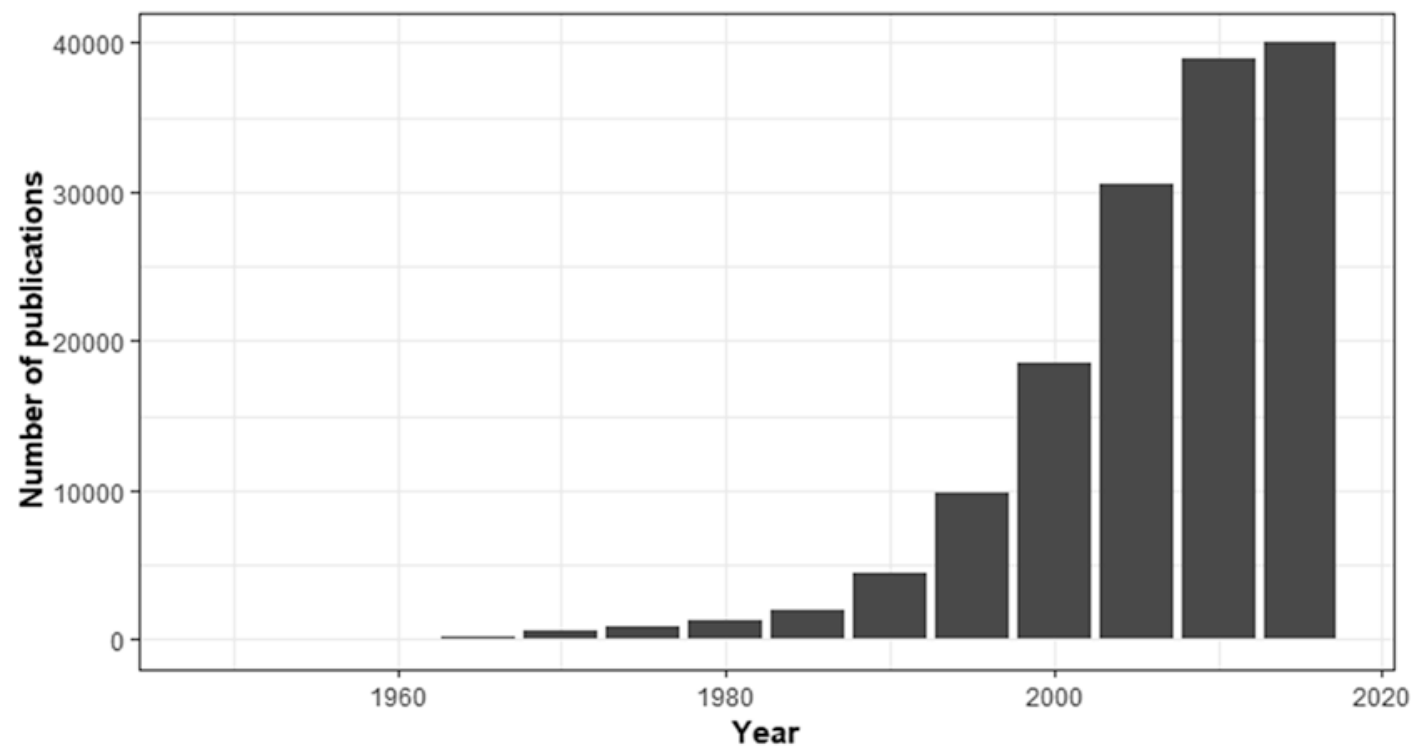

Fig. 5.1 The increase in published marine restoration articles from 1950 to the present day as results of Google Scholar search using the search terms "marine," "restoration," and "ecology" in one search. The past 20 years experienced a near exponential increase in scientific papers related to the topic of marine restoration former, in a coastal area to enhance, for instance, productivity or merely as an afforestation action is not considered an ecological restoration (Elliott et al. 2007). In theory, any action of restoration without a historical reference point cannot be considered as such. But, in practice, only few habitats possess robust information on their historical baselines.

Finally, to allocate financial resources effectively, restoration should target areas in which its feasibility has been assessed (e.g., through ecological modelling) and especially where the environmental conditions are suitable for the survival of the target species. Abiotic conditions need to be checked in advance to see if loss of habitat is irreversible or not (Bellgrove et al. 2017). For instance, if the water conditions are detrimental to the introduction and persistence of the species, the water quality itself should be restored prior to implementing any restoration actions. Bayraktarov et al. (2016) stressed that low survivorship of restored corals was mainly due to inadequate site selection (e.g., sites with high sedimentation rates or strong currents) (Ammar et al. 2000; Fox et al. 2005). The same occurs in restoration efforts of seagrasses which often failed due to planting seagrass shoots at high wave energy locations without anchoring, inappropriate anchoring, or planting at sites with high levels of sediment movement and erosion (Bird et al. 1994; Ganassin and Gibbs 2008). Restoration actions can largely differ in terms of their applied strategies and approaches and whether they are focused at population or habitat levels or at an even broader landscape scale: the ecosystem level. To date, the most explored restoration approach is the habitat level. It focuses on one (or two) species that are known to act as habitat formers (i.e., targeted species are often ecosystem engi- neers that then act as foundation species) (Fig. 5.2). Once reintroduced, these species can provide fundamental ecosystem functions and processes that will ultimately benefit other associated organisms and lead to overall system recovery (Powers and Boyer 2014).

\subsubsection{Habitat-Level Restoration Techniques}

Habitat-level restoration in the marine environment concerns mainly coastal marine habitats, such as salt marshes, coral reefs, seagrasses, oyster reefs, macroalgae, and mangroves (Table 5.1). Attempts to restore these habitats encompass a variety of different techniques such as transplanting different stages of an organism life cycle, in the case of corals, seagrass, and macroalgae, the introduction of artificial substrata colonized by the target species, and planting of mangroves and salt marsh plants (Table 5.2). Restoration actions can in some cases be combined with measures to enhance water quality and improve the hydrodynamic conditions influencing these habitats. Based on a coarse literature review (considering even macroalgae) and information derived from Bayraktarov et al. (2016), the most explored technique, independently from the targeted habitat, is the transplantation approach. Transplantation consists of the movement of the species from a donor site where it is still present to another, where there is the need to restore the vanished habitat. Many of the examples reporting highly successful transplantations in coastal marine habitats are from transplants of entire coral colonies or fragments (branches of the coral) from donor colonies, as well as from coral farming techniques 
a

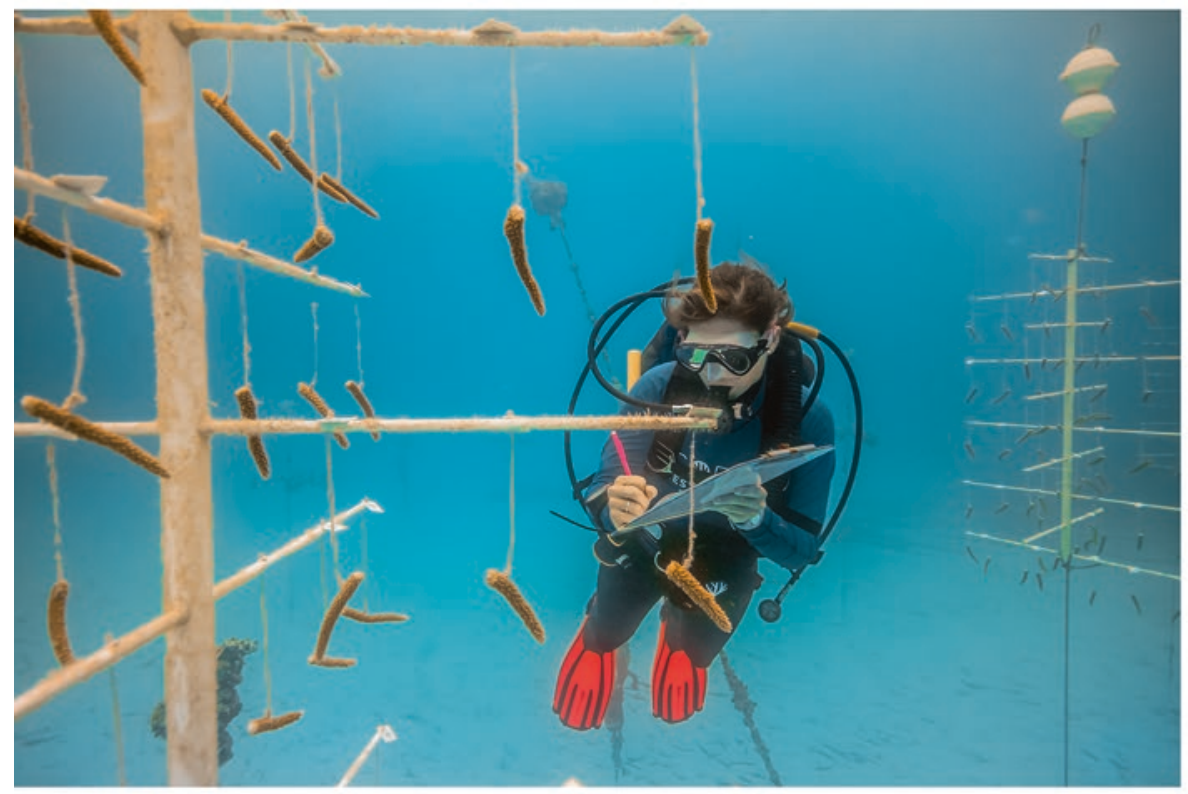

b

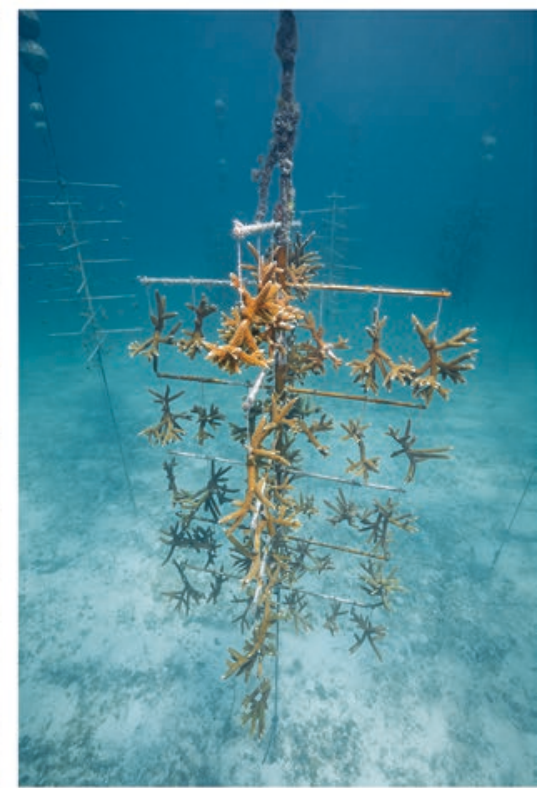

C

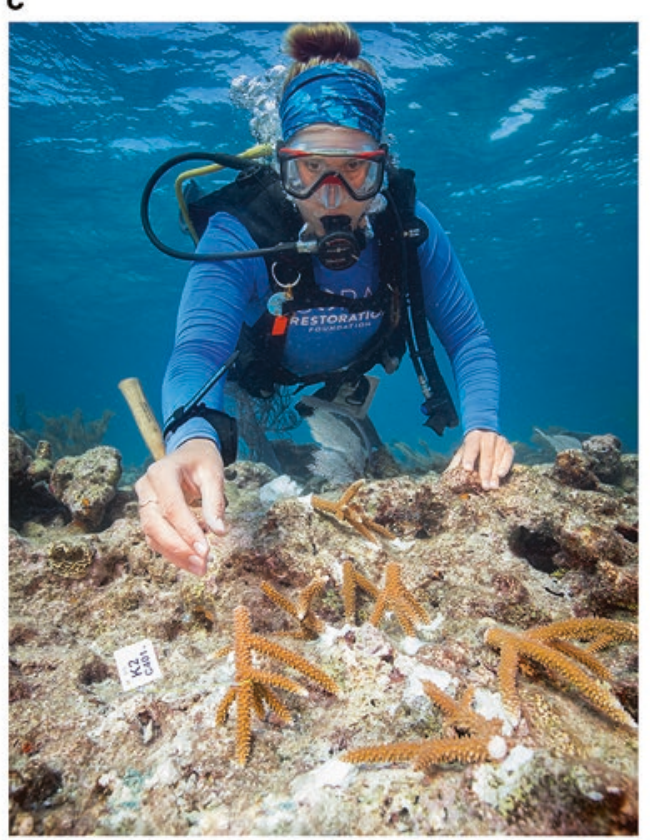

Fig. 5.2 Coral farming of Acroporacervicornis and planting in Key Largo, Florida (USA), performed by the Coral Restoration Foundation (permission by Coral Restoration Foundation ${ }^{\mathrm{TM}}$ )

(Bowden-Kerby 2001; Rinkevich 2005; Edwards and Gomez 2007; Bayraktarov et al. 2016).

Coral farming is the process of collecting fragments of corals from local reefs, raising them in nurseries until mature, and then installing them at the restoration site (Fig. 5.3) (Shaish et al. 2008; Tortolero-Langarica et al. 2014). For seagrasses, the most commonly used technique is the transplantation of seedlings, sprigs, shoots, or rhizomes (Bastyan and Cambridge 2008, Ganassin and Gibbs 2008; Balestri and
Lardicci 2014). In particular, van Katwijk et al. (2016) pointed out that rhizome fragments, anchored using weights, are the most successful way to restore seagrass beds. For macroalgae, the most successful techniques involve the transplantation of both adults and early life stages of the organism (i.e., sporophytes or juveniles) which can be sourced from natural donor sites or aquaculture facilities (Terawaki et al. 2001, 2003; Falace et al. 2006; Yoon et al. 2014). Transplantation techniques have also been the most 
Table 5.1 Frequently used species to restore coastal marine habitats The first priority for a suitable species is the expectation of that species to survive at the site that is being restored. The species are listed randomly, not by proven restoration success. These species are habitat formers which once reintroduced can benefit other species, increase coastal productivity, and act as carbon sinks. These species have mostly resulted in successful restoration efforts (Bayraktarov et al. 2016)

\begin{tabular}{|c|c|c|}
\hline Ecosystem & Species & References \\
\hline \multirow[t]{5}{*}{ Coral reefs } & Acropora spp. & $\begin{array}{l}\text { Edwards and Gomez } \\
\text { (2007) }\end{array}$ \\
\hline & Pocillopora spp. & Johnson et al. (2011) \\
\hline & Porites spp. & \multirow[t]{3}{*}{ Pizarro et al. (2012) } \\
\hline & Merulinascabricula & \\
\hline & Milleporaalcicornis & \\
\hline \multirow[t]{5}{*}{ Seagrasses } & Cymodoceanodosa & $\begin{array}{l}\text { Ganassin and Gibbs } \\
\text { (2008) }\end{array}$ \\
\hline & Zostera spp. & $\begin{array}{l}\text { Bastyan and Cambridge } \\
\text { (2008) }\end{array}$ \\
\hline & Posidonia spp. & \multirow{3}{*}{$\begin{array}{l}\text { Balestri and Lardicci } \\
\text { (2014) }\end{array}$} \\
\hline & Halodule spp. & \\
\hline & Ruppiamaritima & \\
\hline \multirow[t]{5}{*}{$\begin{array}{l}\text { Mangrove } \\
\text { forests }\end{array}$} & Rhizophora spp. & $\begin{array}{l}\text { Goforth and Thomas } \\
\text { (1979) }\end{array}$ \\
\hline & Avicennia spp. & Ainodion et al. (2002) \\
\hline & Laguncularia spp. & $\begin{array}{l}\text { Primavera and Esteban } \\
(2008)\end{array}$ \\
\hline & Bruguiera spp. & \multirow[t]{2}{*}{ Bosire et al. (2008) } \\
\hline & Laguncularia spp. & \\
\hline \multirow[t]{3}{*}{ Oyster reefs } & Crassostreavirginica & Powers et al. (2009) \\
\hline & \multirow[t]{2}{*}{ Ostrea spp. } & Rossi-Snook et al. (2010) \\
\hline & & $\begin{array}{l}\text { Zarnoch and Schreibman } \\
\text { (2012) }\end{array}$ \\
\hline \multirow{4}{*}{$\begin{array}{l}\text { Macroalgae } \\
\text { forests }\end{array}$} & Phyllospora spp. & Falace et al. (2006) \\
\hline & Ulva spp. & Lee et al. (2008) \\
\hline & \multirow[t]{2}{*}{ Cystoseirabarbata } & $\begin{array}{l}\text { Perkol-Finkel and Airoldi } \\
\text { (2010) }\end{array}$ \\
\hline & & Campbell et al. (2014) \\
\hline \multirow[t]{3}{*}{ Salt marshes } & Spartina spp. & Armitage et al. (2006) \\
\hline & Salicornia spp. & Zedler et al. (2003) \\
\hline & Batismaritima & $\begin{array}{l}\text { Castillo and Figueroa } \\
\text { (2009) }\end{array}$ \\
\hline
\end{tabular}

utilized approach for mangroves, with many restoration programs carried out in countries with developing economies, where mangroves forests are located (Proffitt and Devlin 2005; Bayraktarov et al. 2016; Thorhauget al. 2017).

The fact that transplantation techniques are the most suitable for coastal marine habitats is also supported by the wide use of these techniques in terrestrial habitats, where restoration initiatives have been implemented for a longer time than the marine environment to counteract deforestation. Transplantation has also been used in the ecological restoration of estuaries and salt marshes (SER 1998; Zedler et al. 2003; Castillo and Figueroa 2009), which constitute good examples for coastal restoration activities due to the high number of reported successful efforts. Moreover, restoration programs, focused on these transitional water systems, often include an important involvement of private and public stakeholders who have funded long-lasting projects. For instance, the USA started the first restoration program of salt marshes as early as the 1970s (Tsihrintzis 1970).

It is often argued that restoration actions are focused on the present state of ecosystems, not considering the challenges they will face in the future (Harris et al. 2006). Ecological restoration needs to cope with a fast-changing environment which could lead to complications over projects and reduce the final success of restoration programs (Erwin 2009; Havens et al. 2015). Some solutions to this problem have, however, been advocated and utilized in many restoration initiatives. Coral reef restoration, for instance, benefits from advances in selective breeding techniques or the manipulation of the coral microbiome selective breeding (van Oppen et al. 2017).

\subsubsection{Selective Breeding to Increase Restoration Technique Success}

Climate change alters the physicochemical conditions of the ocean (IPCC 2014), causing organisms to adapt to new conditions that are different from the optimum. Since 1992, the idea of implementing genetic approaches to cope with global climate change has been proposed, particularly in terrestrial environments (Ledig and Kitzmiller 1992). Initially, nonnative species that are more tolerant and, therefore, resistant to climate have been introduced to help enhance the resilience of species assemblages that are facing climate change (Ledig and Kitzmiller 1992; Harris et al. 2006). For instance, Ledig and Kitzmiller (1992) proposed to introduce nonnative seeds to planting programs, artificially selecting those that are capable of surviving at higher temperatures. Humanity has been doing this since the domestication of plants and animals, always looking for desirable or specific traits (Hill and Caballero 1992). In the case of tree populations, they mostly rely on phenotypic plasticity to adapt to new conditions (Alfaro et al. 2014).

Climate change impacts in the marine environment become particularly severe when they affect coral reefs. Since climate change is related to ocean acidification, it poses a direct threat to coral reef health (Hoegh-Guldberg et al. 2007; Veron et al. 2009). Increased acidic conditions have detrimental effects on coral calcification and growth when the $\mathrm{CO}_{2}$ concentration exceeds 560 ppm (Kleypas and Langdon 2006). It has, however, been demonstrated that some coral morphotypes or genera can survive extreme conditions of temperature and $\mathrm{pH}$ (Alcala et al. 1982; Lindahl 1998; Bowden-Kerby 2001). Latest global coral bleaching events have sharpened the focus on the use of assisted evolution (i.e., selective breeding and assisted gene flow (Aitken and Whitlock 2013), conditioning or epigenetic program- 
Table 5.2 Most successful restoration techniques in different coastal marine habitats as summarized by Bayraktarov et al. (2016) and a coarse literature review with a particular focus on macroalgae. Macroalgae have not been considered by Bayraktarov et al. (2016), even though along the coasts they are an extremely important habitat formers, vital for coastal biodiversity and ecosystem functions. "Other techniques" do not always include human-mediated reintroduction; they can be facilitation measure

\begin{tabular}{l|l|l|l}
\hline Ecosystem & Transplantation (adult life stages) & Planting (early life stages) & Other techniques \\
\hline Coral reefs & $\begin{array}{l}\text { Transplanting of the whole } \\
\text { colony or fragmented corals; } \\
\text { out-planting }\end{array}$ & $\begin{array}{l}\text { Sexual propagation in aquaria; } \\
\text { transplantation of juveniles }\end{array}$ & $\begin{array}{l}\text { Coral farming facilitated by electrical field; } \\
\text { deployment of artificial reef structures }\end{array}$ \\
\hline Seagrasses & $\begin{array}{l}\text { Transplanting seagrasses (cores } \\
\text { or plugs) }\end{array}$ & $\begin{array}{l}\text { Collecting or aquacultured seeds, } \\
\text { seedlings, or rhizomes for } \\
\text { transplantation }\end{array}$ & $\begin{array}{l}\text { Deployment of hessian bags to stabilize the sandy } \\
\text { bottom }\end{array}$ \\
\hline $\begin{array}{l}\text { Mangrove } \\
\text { forests }\end{array}$ & $\begin{array}{l}\text { Planting mangroves (saplings or } \\
\text { small trees) }\end{array}$ & $\begin{array}{l}\text { Planting mangroves (seeds, } \\
\text { seedlings, or propagules) }\end{array}$ & $\begin{array}{l}\text { Hydrological restoration (facilitation of a natural } \\
\text { recovery) }\end{array}$ \\
\hline Oyster reefs & - & $\begin{array}{l}\text { Hatchery rearing of native oysters } \\
\text { (and seeding) }\end{array}$ & $\begin{array}{l}\text { Creating a no-harvest sanctuary with natural or } \\
\text { artificial substrate }\end{array}$ \\
\hline $\begin{array}{l}\text { Macroalgae } \\
\text { forests }\end{array}$ & Transplantation of adults & $\begin{array}{l}\text { Transplanting of sporophyte, } \\
\text { seedlings, spore, germlings, or } \\
\text { juveniles }\end{array}$ & $\begin{array}{l}\text { Cleaning the substrata from ephemeral algae or } \\
\text { removal of grazers (facilitation to natural recovery); } \\
\text { deployment of artificial substrata }\end{array}$ \\
\hline Salt marshes & $\begin{array}{l}\text { Planting of salt marsh plants } \\
\text { containing plugs }\end{array}$ & $\begin{array}{l}\text { Planting salt marsh seeds, } \\
\text { seedlings, or sods }\end{array}$ & $\begin{array}{l}\text { Construction; excavation and backfilling with clean } \\
\text { soil }\end{array}$ \\
\hline
\end{tabular}

a

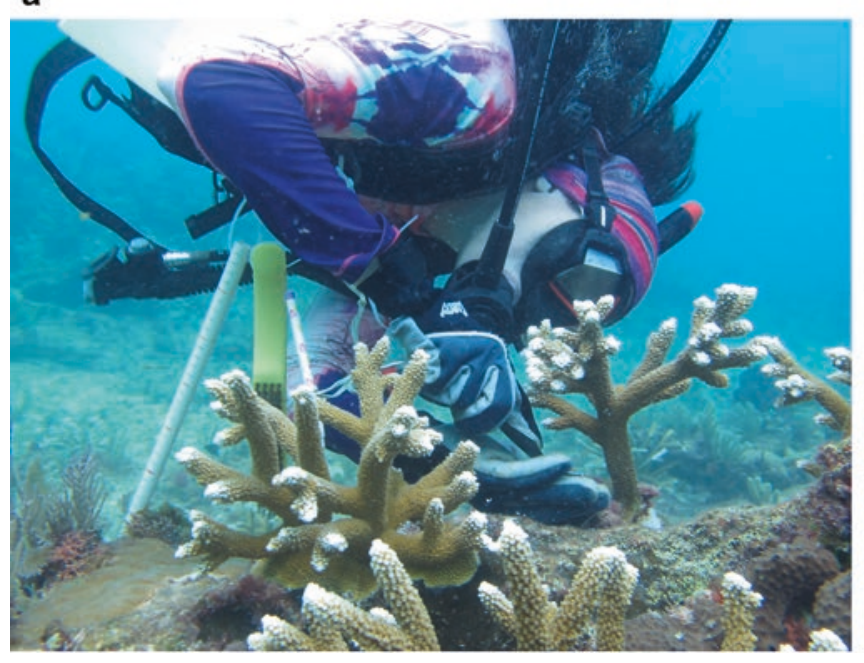

b

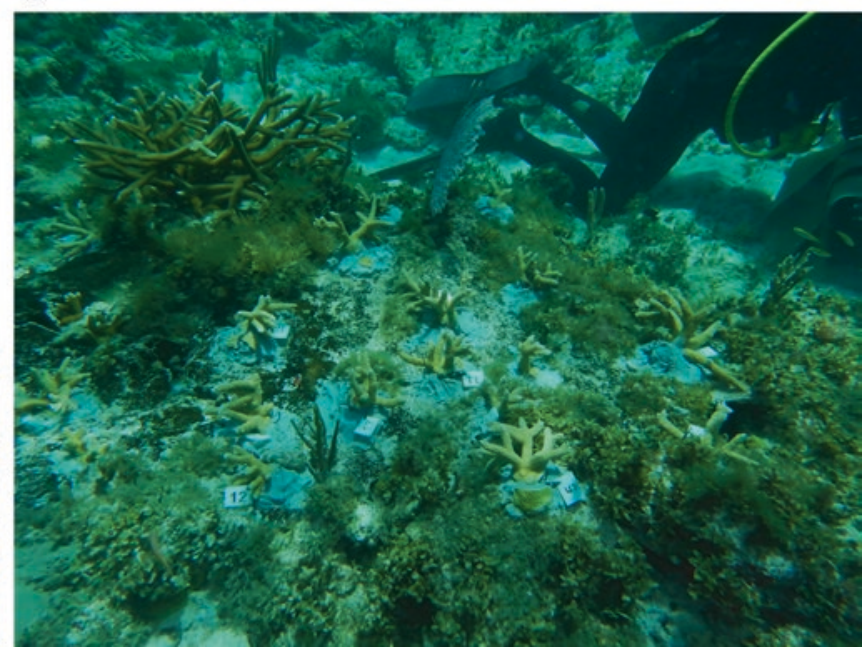

Fig. 5.3 Coral reef restoration in Quintana Roo, Mexico. Permission by Claudia Padilla Souza, Instituto Nacional de Pesca y Acuacultura (INAPESCA)

ming (Torda et al. 2017), the manipulation of the coral microbiome (Bourne et al. 2016), etc.) as a mean to enhance environmental stress tolerance of corals and increase the success of coral reef restoration efforts over longer periods (van Oppen et al. 2017). Genetic tolerance of host and zooxanthellae among heat-sensitive clones would provide enough evidence for change as the habitat moves to higher thermal regimes (Hoegh-Guldberg 1999). Another marine habitat used to attempt genetic selection are mangroves. Mangroves apparently have a better chance to adapt to quickly changing environmental conditions, as plants appear to have higher levels of genetic adaptation to current climate change (Rico et al. 2013). According to Xu et al. (2017), mangrove trees are highly adaptable organisms, although mangroves have the least diverse genome in comparison with other usually restored marine habitats, which may be due to the continual habitat turnover caused by the exposure to rising and falling sea levels in the geologically recent past. Mangroves are, therefore, thought to have better chances to thrive throughout the Climate Change Era. However, any optimism about their resilience at these times might be premature (Guo et al. 2018). Nevertheless, selecting individuals with the most appropriate genomes within the different mangrove species would constitute the best choice to use the most suitable organisms that could face future adverse and extreme conditions.

In the tropics, many macroalgal species live close to their thermal limits, and they will have to upregulate their response 
to tolerate sublethal temperature exposure. However, the effects of elevated $\mathrm{CO}_{2}$ concentrations and thermal acclimation are not well-described for macroalgal forests (Koch et al. 2012). Cole et al. (2013) demonstrated that freshwater macroalgae of the genus Oedogonium are capable of assimilating higher amounts of $\mathrm{CO}_{2}$ above present-day concentrations; thus, they are capable of improving their carbon storage features with consequences for their biomass. One of the most important ecosystem services is the sequestration and storage of $\mathrm{CO}_{2}$ by algae, plants, and coral reefs, reducing the process of global warming (Moberg and Folke 1999; Corlett and Wescott 2013). With this in mind, the use of genetic tools, such as translocating genes from Oedogonium sp. to other algae species, could present an opportunity to modify organisms in a way to enhance their carbon uptake capacity and, therefore, remove larger amounts of $\mathrm{CO}_{2}$ from the atmosphere and potentially smoothen the consequences of the impacts related to climate change.

Although enhancing specific traits on certain species using genetic technologies would sound like a good idea, specifically to an improvement to marine restoration success, in the end a rather philosophical question arises: Life always finds its way. No matter how bad conditions might get, there is always an alternative road. Thus, are we promoting/ encouraging the next step of evolution or are we stopping it by selecting specific traits that are of interest to us? And, thus, how should we elaborate appropriate strategies to make restoration successful in a fast-changing world?

\subsection{Measurements of Restoration Success}

\subsubsection{Survival}

To date, restoration success has mainly been assessed as the average survival of the reintroduced species. However, even when survival of targeted species is high, assessment of regain in ecosystem functionality is often accounted for. Hence, it is difficult to see if the ecosystem is fully restored.

In fact, in the database of Bayraktarov et al. (2016), 61\% of all observations on marine coastal restoration provided information on survival of restored organisms as an itembased success indicator. While Bayraktarov et al. (2016) did not include macroalgae records, they have been considered in this analysis, screening all peer-reviewed articles concerning attempts of macroalgae restoration. Macroalgae shall be included in the most restored habitat formers together with those already included in Bayraktarov et al. (2016): coral reefs, seagrasses, mangroves, oyster reefs, and salt marshes.

Macroalgal forests (i.e., kelp forests or Cystoseira spp., Fucus spp., Sargassum spp., Phyllosphora spp.) are disappearing worldwide, prompting many scientific groups all over the world to implement their restore (e.g., Terawaki et al. 2003; Falace et al. 2006; Perkol-Finkel et al. 2012). Therefore, the dataset of Bayraktarov et al. (2016) was supplied by other ten articles in which success of macroalgae restoration was assessed. Articles regarding macroalgae restoration available in the literature (up to 2016) were more than ten, but those are the only ones measuring success as survival of target species. To be consistent with the analysis of Bayrakratov et al. (2016), just those ten have been considered.

The average survival per habitat after restoration are $56.3 \%$ for coral reefs, $40.4 \%$ for seagrasses, $52.2 \%$ for mangroves, $55.1 \%$ for oyster reefs, $22.9 \%$ for macroalgae, and $57.2 \%$ for salt marshes. The number of studies in which the success of habitat restoration was assessed by survival (the only ones considered in this analysis) was different among habitats, revealing the fact that some habitats have been more explored in terms of restoration than others. This might be a cause of different success rates (Fig. 5.4). It can be claimed that the higher the number of restoration attempts, the more we succeed. On one hand, this agrees with low macroalgae restoration success (5.0\% of median survival) (the least studied habitat in terms of restoration) and salt marshes and coral reef, the most restored and the most successful (with $64.8 \%$ and $64.5 \%$ of median survival, respectively). On the other hand, this disagrees with seagrass restoration, which is a well-explored habitat in terms of restoration, but that is not so successful (38.0\% of median survival). Many studies, however, agreed on the specific challenges related to seagrass restoration (Ganassin and Gibbs 2008; van Katwijk et al. 2016; Cunha et al. 2012).

\subsubsection{Ecosystem Services}

Evaluating the success of restoration initiatives is extremely challenging. The use of one metric over another can result in profoundly different outcomes which in turn has important consequences for the management decisions and actions taken by stakeholders and decision makers regarding restoration projects. Therefore, it is of paramount importance to use the appropriated metrics and assessment techniques.

In theory, restoration activities can only be considered successful when ecosystem functioning and habitat resilience capacity are reverted to the state preceding the degradation (Peterson et al. 2003; Shackelford et al. 2013). These outcomes are difficult to evaluate. Therefore, assessment studies are looking for proxies. In the marine environment, most studies focus on rudimentary performance metrics (Ruiz-Jaen and Aide 2005). For instance, oyster reef restoration monitoring in the Gulf of Mexico used three success metrics based on sustainability of oysters: presence of vertical structure above the bottom, presence of live oysters, and evidence of recruitment (Powers et al. 2009; La Peyre et al. 


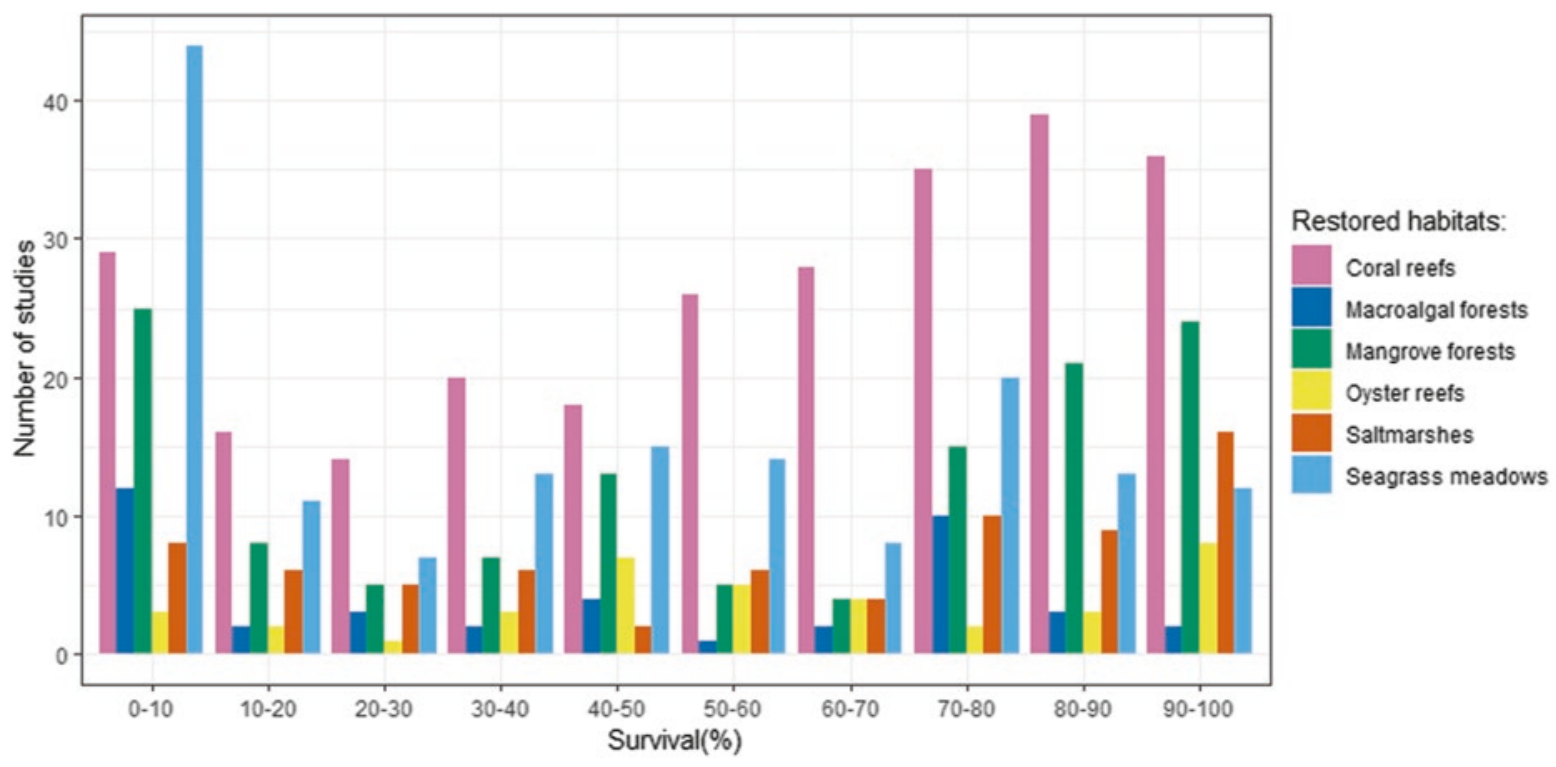

Fig. 5.4 Frequency of success in restoration, measured as percentage of survival reported by published articles until 2016 across the six mostly restored coastal marine habitats

2014). The most common metric used in all marine habitats is survival rate (Ruiz-Jaen and Aide 2005), whereas, in the terrestrial environment, assessment techniques are predominantly based on parameters such as biodiversity, vegetation structure, or ecological functions (Ruiz-Jaen and Aide 2005). Restoration science in marine coastal ecosystem is still in an early phase compared to terrestrial ecosystems (Suding 2011; Bayraktarov et al. 2016). Furthermore, monitoring programs base their evaluation of restoration success on short-term studies, even though previous research has repeatedly demonstrated that longer time scales provide better estimates of restoration success, since ecosystem services need longer time periods to recover (Bell et al. 2008; Bayraktarov et al. 2016). Better metrics need to be adopted in the marine environment to improve the assessment of restoration success, incorporating ecosystem services-based parameters (Fonseca et al. 2000; Paling et al. 2009). Ecosystem servicesbased parameters could facilitate the inclusion of economic and social interests in restoration projects while increasing biodiversity (Benayas et al. 2009; Adame et al. 2015).

Marine restoration monitoring can provide incorrect assessments of the outcome of restoration projects. They typically use survival of organisms transplanted (e.g., seagrass, mangroves, corals), whereas reviews advise to follow the path of terrestrial restoration monitoring that uses biodiversity, ecosystem structure, or ecological functions instead (Bayraktarov et al. 2016). It has been stated that restoration goals should focus on the provision of ecosystem services (Benayas et al. 2009). Therefore, the use of ecosystem services in restoration assessments might provide a better estimate of project success (Fonseca et al. 2000; Bayraktarov et al. 2016).
The use of ecosystem services-based metrics in restoration projects is quite new. To obtain the scale of the area to be restored to compensate for the habitats lost or degraded, a habitat equivalency analysis (HEA) was created by NOAA in 1997 (NOAA 1997). This analysis computes the interim of loss ecosystem services during the time the ecosystem was destroyed and the time where it reaches standards of equivalency after restoration. If an ecosystem is destroyed but its restoration takes place immediately after and reaches standards of ecological functions equivalent to those present previous to the perturbation in a short time, this interim would be relatively low. However, if the restoration takes place a long time after perturbation, and if the ecosystem takes a long time to reach the standards of equivalency, this interim would be higher. The novelty of this analysis consisted in integrating specific resource-based metrics as a proxy for the loss services. In an US federal court case, Fisher used seagrass shoot density as a proxy to provide compensation for the loss of sea grass within the Florida Keys National Marine Sanctuary (Fonseca et al. 2000). This protocol was demonstrated to be quite flexible and applicable to a wide range of habitats (Fonseca et al. 2000; Cabral et al. 2016; Grabowsky et al. 2012). Another tool to investigate the ecosystem services across a landscape is the InVEST (Integrated Valuation of Ecosystem Services and Trade-offs), which is based on cartographic representation of the ecological information within an area (Tallis and Polasky 2009). InVEST allows to estimate the change in ecosystem services in response to different management scenarios (Guerry et al. 2012). HEA and InVEST tools are utilized prior to the onset of restoration work, providing estimates of the required scale needed to compensate for the lost area and identifying the 
most appropriate location site of the restoration initiative. They set the outcomes of a project based on ecosystem services-based parameters, facilitating their use as metrics in assessment studies. The combined uses of these investigative tools have shown to provide valuable results as it delivers relevant information for decision makers in an integrated way using an ecosystem services framework as common currency and to be easily adapted to include more constraints and/or other ecosystem services (Cabral et al. 2016). However, evaluating restoration success using ecosystem services-based metrics is an emerging field in marine ecology, except for coastal wetlands (Zhao et al. 2016). Such metrics already exist for this habitat, such as the rapid assessment method (Galv-RAM) which uses a combination of biotic and abiotic parameters to obtain an ecosystem index score (Staszak and Armitage 2012). New metrics are being investigated for other habitats, such as the determination of food web structure through isotopic analysis for restored macroalgae beds (Kang et al. 2008), the use of fish assemblages to assess seagrass restoration success (Scapin et al. 2016), or the use of fish tracking and habitat use to assess the recovery of an estuary (Freedman et al. 2016). It is, however, a great challenge to determine the appropriate resourcebased parameter to integrate those tools and then to estimate the recovery rate of ecosystems (Peterson et al. 2003; Carpenter et al. 2009). Moreover, the concept and metrics of marine coastal ecosystem services are still in their infancy and require further development (Liquete et al. 2013). The chosen metrics also have to match with the rate of ecosystem services recovery which in most case exceeds the time scale of most evaluation studies of restoration success (often $<5$ years) (Bell et al. 2008; De Groot et al. 2012; Bayraktarov et al. 2016). Recommendations to develop and use ecosystembased metrics were formulated almost 20 years ago (Fonseca et al. 2000). Yet metrics used in marine restoration studies rarely focused on the recovery of ecosystem functions or services, and this might have led to restoration failure (Bayraktarov et al. 2016; Hein et al. 2017). Further research is needed to develop new ecosystem-based metrics, setting the appropriate goals for marine restoration to outweigh services loss after a perturbation.

\subsection{Ecosystem Services as a Method to Link Restoration to Socioeconomic Sciences}

The concept of ecosystem services plays an important role in the cost-benefit analysis of human activities impacting the natural capital. This concept has, therefore, been increasingly used in the context of socioeconomics. Associating a value with a service or resource is a powerful tool to high- light the ecological and also the financial loss because of anthropogenic impacts on habitats and ecosystems (Worm et al. 2006; Salomon and Dahms 2018). The Millennium Ecosystem Assessment (MEA 2005) has led to an exponential increase of scientific interest in this topic, from 2.5 papers per year during 1997-2006 to 25 papers per year since 2007 (Liquete et al. 2013). Marine coastal ecosystems can no longer be considered as inexhaustible, and their value to society and the costs associated with their loss and degradation need to be properly accounted for (Costanza et al. 1997; Carpenter et al. 2006; De Groot et al. 2012). Valuation of ecosystem services is nowadays considered as exceptionally important to contribute to the conservation and restoration of threatened and lost habitats. Economists demonstrated that restored, healthy habitats will generate value for both households and industry (Barbier et al. 2011). Recent studies confirm the general paradigm stating that ecosystem services would return through habitat restoration (Benayas et al. 2009) for mangroves (Rönnbäck et al. 2007), seagrasses (Reynolds et al. 2016), and even a whole estuarine system (salt marsh, mangrove, seagrass) (Russel and Greening 2015). New methods of ecosystem service valuation suggest that the economic benefits of restoration can outweigh their costs (Bullock et al. 2011; Grabowski et al. 2012; Speers et al. 2016; Adame et al. 2015). Cost-benefit computation derived from ecosystem services provided by restored habitats could incentivize managers and stakeholders to increase financial investment into marine restoration projects.

Valuation of ecosystem services has been a launch pad to raise interest and awareness of scientists and the general public to the socioeconomic importance of habitats and the services they provide. It has had an enormous impact on the perception of restoration as a way to improve human wellbeing (Costanza et al. 2014). However, it is challenging to estimate the value of many ecosystem services, as most of them do not have a market value. To compute the benefit to cost ratio of a restoration project, one needs to know which ecosystem services are provided by the habitat and how much financial value can be associated with them (Speers et al. 2016). Reference and meta-analysis studies estimating those parameters have been undertaken (Costanza et al. 1997, 2014; MEA 2005; Barbier et al. 2011; De Groot et al. 2012; Salomidi et al. 2012). The most commonly used estimation was obtained through the global assessment of The Economics of Ecosystems and Biodiversity (TEEB), reported by De Groot et al. (2012). This estimate was an international initiative undertaken by the UN Environment program. It collected information from 320 publications and published an overview of the value of ecosystem services provided by ten main biomes, from fishery stock to cultural and spiritual heritage (De Groot et al. 2012; Schröter et al. 2014). The 
estimates range from 490 international $\$ / y e a r^{1}$ for a hectare of open ocean to $350,000 \mathrm{int} \$ / y e a r$ for a hectare of coral reefs. Seagrass and algae beds are estimated to be 28,916 int\$/year per hectare and mangroves and tidal marshes up to 193,843 int\$/year per hectare. These values include a mix of market and nonmarket values, with the latter being the most important (De Groot et al. 2012). Those nonmarket values are mainly estimated through existing studies of households' willingness to pay to protect the habitats (Mendelsohn and Olmstead 2009; Barbier et al. 2011). The TEEB report was picked up extensively by mass media and alongside the Millennium Assessment (MA) greatly influenced the communication to policy makers (Schröter et al. 2014). Costanza et al. (2014) used the TEEB report to determine the global economic loss for the whole marine environment in response to land use change between 1997 and 2011, obtaining a figure up to 10.9 trillion\$/year, mainly driven by coral reef degradation (Costanza et al. 2014). The interconnection between habitats may also greatly influence ecosystem services on a spatiotemporal scale (Barbier et al. 2011). A coral reef will not provide the same ecosystem services if mangroves or seagrass meadows are present or absent from nearby coastal area (Moberg and Folke 1999). More studies are required to assess the different ecosystem services delivered by "outsider" habitats (important but underrepresented in science) in a broader geographical range, taking into account the connectivity between habitats and spatiotemporal variability of the ecosystems.

Restoration projects have commonly been funded by governments, by private companies restoring a given ecosystem as compensatory measures of previous degradation and/or loss of habitat elsewhere, or through biobanking and biodiversity offset initiatives (Bullock et al. 2011). Valuation of ecosystem services has led to another way of funding which would address both ecological and social issues with ecosystem sustainability and poverty alleviation, respectively (Farley and Costanza 2010). Payment for ecosystem services (PES) schemes are emerging as new market-based approaches for restoration projects, based on the argument that people depend on ecosystem services and the way to ensure their continued provision is to pay for them (Redford and Adams 2009; Muradian et al. 2010). The previous statement has been increasingly used worldwide, especially in the terrestrial environment (Farley and Costanza 2010; Bullock et al. 2011). In the marine environment, the main market-based ecosystem service that could be integrated into a PES is car-

\footnotetext{
${ }^{1}$ The international dollar, or the Geary-Khamis dollar, is a hypothetical unit of currency that is used to standardize monetary values across countries by correcting to the same purchasing power that the US dollar had in the USA at a given point in time (De Groot et al. 2012).
}

bon storage through the reducing emissions from deforestation and forest degradation (REDD+) set of international policies (Bullock et al. 2011; Locatelli et al. 2014). Blue forests (mangroves, seagrass, and macroalgae) are known to store a great quantity of carbon into their biomass or soil which works as a buffer for climate change (Nelleman et al. 2009; McLeod et al. 2011; Himes-Cornell et al. 2018). Seagrasses cover less than $0.2 \%$ of ocean bottom; yet they are estimated to account for $10 \%$ of the global carbon sequestered in marine sediment (Fourqurean et al. 2012), while mangrove accounts for 14\% (Alongi 2012). Therefore, they are strong candidates for PES projects, especially mangroves due to a higher knowledge on ecosystem services and their financial valuation (Liquete et al. 2013; Locatelli et al. 2014). As mangroves are mainly present in developing countries, mangrove PES restoration schemes could contribute to alleviate poverty within the local coastal communities through restoration of ecosystem services, employment in restoration program, and benefit from the PES funds while tackling the issue of climate change at a global scale (Carpenter et al. 2006; Martinez-Alier 2014; Rodríguez 2018). A small-scale mangrove-based PES project already exists in Kenya, called "Mikoko Pamoja" (Fig. 5.5; see www.eafpes.org), but largerscale projects are still difficult to implement due to the lack of local and regional institutional frameworks that could cope with the complexity of such schemes (Bullock et al. 2011). Even though much criticism has been voided against PES schemes, especially on their carbon-centric approach, neglecting other goods and services and their long-term viability, it is thought to be a vital tool to address the issue of the significance of restoration ecology to stakeholders and decision makers (Redford and Adams 2009; Bullock et al. 2011). Its implementation could be facilitated through the development of innovative tools such as ecosystem services mapping exercise.

The use of spatial analyses is extremely interesting in restoration ecology to select areas to restore with the highest cost-benefit ratio. A study by Adame et al. (2015) developed a novel restoration approach based on biodiversity and ecosystem services provided by a mangrove forest. The use of physical parameters to estimate ecosystem services might be tricky, but they assumed it to be more accurate than the common restoration area selection based on accessibility (Adame et al. 2015). These analyses do, however, have several limitations mainly due to a lack of knowledge in marine ecosystem boundaries, services, and connectivity (Liquete et al. 2013). Improvements in modelling and mapping technologies could, therefore, provide better information to advice and steer future ecosystem services policies, helping them to meet goals of sustainability of ecosystem services delivery. 
Fig. 5.5 Local woman planting mangrove juveniles (a) in Gazy Bay Boardwalk, Kenya (b). Permission of Mark Huxham (www. aces-org.co.uk/)

\section{a}

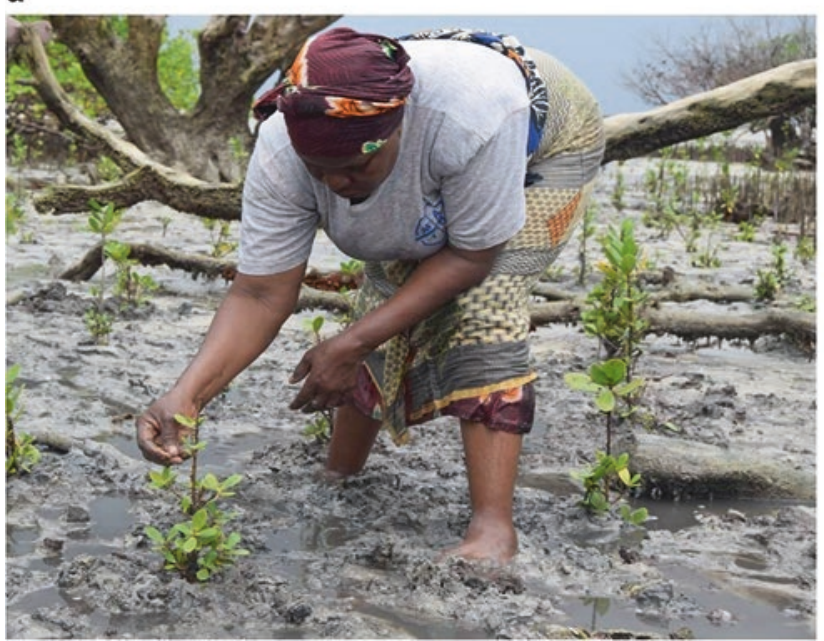

b

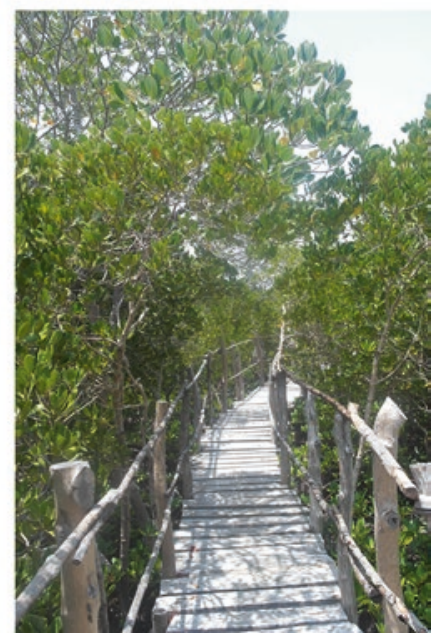

\subsection{Discussion}

Marine restoration ecology is an emerging field which could potentially become the main discipline in ecological science in the next decades. To reach this goal, reviews of success and failures are extremely important to address the main challenges faced. It will allow future projects to find solutions to these challenges and improve this field. Ecological restoration is critical for the persistence of marine habitats (Aronson and Van Andel 2012), and therefore this article provides important information on the relative success of habitat-based restoration and address the main challenges to improve it (Hobbs 2007; Zhang et al. 2018).

Different restoration methods have been utilized to restore habitats (Rinkevich 2005; Bastyan and Cambridge 2008; Ganassin and Gibbs 2008; Balestri and Lardicci 2014; Bowden-Kerby 2001; Tortolero-Langarica et al. 2014; Bayraktarov et al. 2016; Zhao et al. 2016). Transplantation has proven to be the most effective tool for most types of habitats (Bayraktarov et al. 2016). Restoration success is, however, highly dependent on the type of habitat. Highest restoration success is found within coral reefs and salt marshes, which are also the best studied habitats in terms of restoration techniques. Restoration success in the marine environment is more dependent of habitat-based research rather than financial input to the projects (Bayraktarov et al. 2016). Habitat-based research might include studies on topdown control of transplants by grazers and predators which is an important factor influencing marine restoration success (Zhang et al. 2018). Few studies on top-down interactions were directly employed and tested in restoration (four studies, $1 \%$ ), but they were consistently found to have a significant effect on restoration success (Zhang et al. 2018). Also more studies on intra- and interspecies facilitation processes could lead to improved restoration success as recent research demonstrated that salt marsh restoration yield doubled simply by planting marsh grass plugs in aggregate (thus ameliorating abiotic stressors via increased intraspecific facilitation) (Silliman et al. 2015).

Global warming is an upcoming threat to marine habitats. Few are known about habitats' resilience to this threat. Each of them will be affected differently. Coral reefs will be highly affected by the increased seawater temperature and acidity (Veron et al. 2009). On the contrary, other habitat formers could benefit from an increased $\mathrm{CO}_{2}$ concentration. The photosynthetic rates of seagrasses are $\mathrm{CO}_{2}$-limited (Beer and Koch 1996). A study performed by Palacios and Zimmerman (2007) with the eelgrass Zostera marina, a temperate species, demonstrated that an increased $\mathrm{CO}_{2}$ content in the atmosphere and oceans would lead to an increased area-specific productivity of seagrass meadows. A similar study performed by Ow et al. (2015) with three tropical seagrass species found the same result, yet explaining that responses were variable between species. These studies reinforce the emerging paradigm stating that seagrass meadows are likely to benefit significantly from a high- $\mathrm{CO}_{2}$ world (Zimmerman et al. 2017). Acclimation and resilience capacity, alongside the genetic potential of marine habitats, need to be properly accounted for to address their vulnerability to global warming. While global warming might reduce the success of marine restoration, an inverse relationship also exists as marine habitats are known for their great capacity of carbon storage. Their restoration could be utilized as a strategy to buffer global warming (Ledig and Kitzmiller 1992; Harris et al. 2006). Restoring more and more degraded habitats would result in an increased carbon storage capacity of coastal marine environments (McLeod et al. 2011). This newly achieved capacity could then be maintained throughout future scenarios of global warming via the selection of adapted morphotypes and improved species plasticity. 
Van Oppen et al. (2015) stressed the need for quick and reliable answers to the rapid changes. In the particular case of coral reefs, the authors revised the idea of assisted evolution as a good approach, agreeing, to some extent, with the ideas expressed in this work. Due to the lack of knowledge about how manipulation at the genetic level would interfere with natural processes, there is still uncertainty regarding the so-called genetically modified organisms (GMOs). Although in recent times, there has been an advancement in the knowledge regarding the evolutionary mechanisms, information is not enough to determine whether they will be, indeed, the best way to proceed in terms of artificial selection to increase the reach of ecological restoration programs.

These restoration strategies do not absolutely ensure the success of the projects, as it requires the development of reliable metrics. The use of parameters based on the return of ecosystem services provision is advocated as the most viable option (De Groot et al. 2012; Bayraktarov et al. 2016). Not all habitats have, however, been studied with the same attention, and there is still much to discover about their ecological functions leading to the provision of ecosystem services (Liquete et al. 2013). The use of the tools prior to restoration actions, such as the HEA protocol, combined with other tools such as InVEST, would provide clear objectives to marine restoration projects related to the provision of ecosystem services (Cabral et al. 2016). It would then be easier to develop and implement ecosystem services-based metrics to estimate restoration success during monitoring studies. Such metrics already exist for salt marshes and could be regarded as a foundation to develop other habitat-specific metrics (Staszak and Armitage 2012). They would also provide a common base to compare restoration projects in different habitats, leading to a better understanding of success and failure of marine ecosystem restoration. The need to improve communication between stakeholders and the general public has been repeatedly highlighted and would be aided by the use of ecosystem service metrics (Costanza et al. 2014; Nordlund et al. 2018). Reliable estimates of restoration success provided by these metrics would facilitate the involvement of stakeholders within these projects. Restoration has an underlying force residing within its socioeconomic aspect. Valuation of ecosystem services through global assessments, such as the TEEB and the MEA, has increased the awareness of the general public about the catastrophic consequences of habitat loss on the society as well as economy. They have greatly influenced stakeholders' perception of restoration (Costanza et al. 2014). An increased awareness of the ecological and financial gains obtained from ecological restoration through better valuation of ecosystem services will help decision makers to have the right judgment on feasibility and outcomes of restoration projects.
Many habitats in need to be restored are located in developing countries. Therefore, awareness of local communities' influence on ecosystem goods and services should involve and represent locals in restoring degraded habitats. Bottom-up management of conservation areas and restoration projects give more value and ownership to the local community which will then have an incentive to self-enforce any necessary policies. This will provide locals with the tools to establish sustainable living conditions and address poverty alleviation (Redford and Adams 2009; Farley and Costanza 2010; Locatelli et al. 2014). Moreover, if locals are taught to monitor the recovery of ecosystem services, these jobs can even be long-lasting. The Mikoko Pamoja project success is linked to the inclusion of Gazi and Makongeni communities (Fig. 5.5). They participate in the seeding of mangroves and benefit from the PES income with which they provide clean water and educational material to school children, mangrove conservation, and restoration and employ a full staff member to coordinate the project (UNEP and CIFOR 2014). The communities benefit from other mangrove-related income such as ecotourism with the "Gazi Bay Boardwalk" (Fig. 5.5) (Wylie et al. 2016). This project won the Equator Prize in 2017, rewarding outstanding community efforts to reduce poverty through the conservation and sustainable use of biodiversity (see also www.equatorinitiative.org). While this small-scale project was a success, it seems much less realistic to realize a similar one on a larger scale due to a lack of policy frameworks (Reford and Adams 2009; Bullock et al. 2011; Muradian and Rival 2012). The implementation of policies fostering restoration applications, such as the REDD+, is a necessary step to enhance projects on temporal and spatial scales.

Marine habitat restorations are win-win projects, in which all parts benefit from it. Locals regain lost ecosystem services and, if they are included in the management project, also benefit from long-lasting jobs. Stakeholders will see their investment refunded in the following years using PES schemes. The global population also benefits from these projects which, through the carbon storage capacity of coastal ecosystems, buffer global warming. Bottom-up management systems are now considered as the main method to implement long-term restoration projects. The standardization process and methods by the private sector could represent another way to accelerate the implementation of such projects. The inclusion of locals could guarantee a larger spatial and temporal scale for the projects, a higher investment fostered through PES schemes and/or similar approaches, and the implementation of protocols habitat by habitat. For instance, industrializing the process to maintain and keep enhanced coral stocks will benefit ecological restoration, but it will also be a great opportunity for aquarists, therefore, creating a branch of business with a potentially big 
money income and a chance to have organisms better adapted to greater ranges to environmental conditions (Van Oppen et al. 2015). Within this context, the mass production of organisms capable of tolerating higher stress conditions would be an option, but further investigation is needed.

\subsection{Conclusion}

In conclusion, restoration is not a better approach than passive conservation; both strategies work together to reach common goals to protect the natural capital (Elliott et al. 2007; Hobbs 2007; Zhang et al. 2018). We emphasize the fact that assisting natural recovery of ecosystems is no longer an option as their unassisted recovery rate is negligible and cannot cope with the pace of habitat loss. Restoration has to be seen as an integral part of our future ecosystem longevity and requires an urgent focus and implementation to address rapid changes and loss caused by both climate change and multiple direct human-related impacts. Marine restoration projects are not always successful. Failures are mainly due to a lack of habitat-based research in a broader geographical range and of reliable success metrics. Valuation of ecosystem services to increase public and stakeholders' awareness is an important step in marine habitat restoration. It would also improve the use of payment for ecosystem services schemes which are a useful tool to implement bottom-up management of marine restoration projects. Marine habitat restorations are win-win projects: they increase biodiversity, enforce local communities, and buffer climate change. We have the abilities to force such change; it is now time to unite our efforts and undertake the path of ecological restoration for the good of all.

\section{Appendix}

This article is related to the YOUMARES 9 conference session no. 6: "The challenge of marine restoration programs: habitats-based scientific research as a key to their success." The original Call for Abstracts and the abstracts of the presentations within this session can be found in the Appendix "Conference Sessions and Abstracts", Chapter "5 The challenge of marine restoration programs: habitats-based scientific research as a key to their success", of this book.

\section{References}

Abelson A, Halpern BS, Reed DC et al (2015) Upgrading marine ecosystem restoration using ecological-social concepts. Bio Science 66(2):156-163

Adame MF, Hermoso V, Perhans K et al (2015) Selecting costeffective areas for restoration of ecosystem services. Conserv Biol 29(2):493-502
AinodionMJ, RobnettCR, AjoseTI (2002) Mangrove restoration by an operating company in the Niger Delta.Proceedings of the International Conference on Health, Safety and Environment in Oil and Gas Exploration and Production. Kuala Lumpur, pp 1001-1014

Airoldi L, Beck MW (2007) Loss, status and trends for coastal marine habitats of Europe. Oceanogr Mar Biol 45:345-405

Airoldi L, Balata D, Beck MW (2008) The gray zone: relationships between habitat loss and marine diversity and their applications in conservation. J Exp Mar Biol Ecol 366(1):8-15

Aitken SN, Whitlock MC (2013) Assisted gene flow to facilitate local adaptation to climate change. Annu Rev EcolEvolSyst 44:367-388

Alcala AC, Gomez ED, Alcala C (1982) Survival and growth of coral transplants in Central Philippines. Kalikasan 11(1):136-147

Alfaro RI, Fady B, Vendramin GG et al (2014) The role of forest genetic resources in responding to biotic and abiotic factors in the context of anthropogenic climate change. For Ecol Manag 333:76-87

Alongi DM (2012) Carbon sequestration in mangrove forests. Carbon Manag 3(3):313-322

Ammar MSA, Amin EM, Gundacker D et al (2000) One rational strategy for restoration of coral reefs: application of molecular biological tools to select sites for rehabilitation by asexual recruits. Mar Pollut Bull 40(7):618-627

Armitage AR, Boyer KE, Vance RR et al (2006) Restoring assemblages of salt marsh halophytes in the presence of a rapidly colonizing dominant species. Wetlands 26:667-676

Aronson J, Van Andel J (2012) Restoration ecology and the path to sustainability. In: Van Andel J, Aronson J (eds) Restoration ecology: the new frontier. Wiley, Chichester, pp 293-304

Balestri E, Lardicci C (2014) Effects of sediment fertilization and burial on Cymodoceanodosa transplants; implications for seagrass restoration under a changing climate. Restor Ecol 22:240-247

Barbier EB, Hacker SD, Kennedy C et al (2011) The value of estuarine and coastal ecosystem services. Ecol Monogr 81(2):169-193

Bastyan GR, Cambridge ML (2008) Transplantation as a method for restoring the seagrass Posidoniaaustralis. Estuar Coast Shelf Sci 79:289-299

Bayraktarov E, Saunders MI, Abdullah S et al (2016) The cost and feasibility of marine coastal restoration. Ecol Appl 26(4):1055-1074

Beck MW, Brumbaugh RD, Airoldi L et al (2011) Oyster reefs at risk and recommendations for conservation, restoration, and management. Bioscience 61(2):107-116

Beer S, Koch E (1996) Photosynthesis of marine macroalgae and seagrasses in globally changing $\mathrm{CO}_{2}$ environments. Mar Ecol Prog Ser 141:199-204

Bell SS, Tewfik A, Hall MO et al (2008) Evaluation of seagrass planting and monitoring techniques: implications for assessing restoration success and habitat equivalency. Restor Ecol 16(3):407-416

Bellgrove A, McKenzie PF, Cameron H et al (2017) Restoring rocky intertidal communities: lessons from a benthic macroalgal ecosystem engineer. Mar Pollut Bull 117(1-2):17-27

Benayas JMR, Newton AC, Diaz A et al (2009) Enhancement of biodiversity and ecosystem services by ecological restoration: a metaanalysis. Science 325(5944):1121-1124

Bird KT, Jewett-Smith J, Fonseca MS (1994) Use of in-vitro propagated Ruppiamaritima for seagrass meadow restoration. J Coastal Res 10:732-737

Bosire JO, Dahdouh-Guebas F, Walton M et al (2008) Functionality of restored mangroves: a review. Aquat Bot 89(2):251-259

Bourne DG, Morrow KM, Webster NS (2016) Insights into coral microbiome: underpinning the health and resilience of coral reef systems. Annu Rev Ecol Evol 70:317-340

Bowden-Kerby A (2001) Low-tech coral reef restoration methods modeled after natural fragmentation processes. Bull Mar Sci 69(2):915-931

Bullock JM, Aronson J, Newton AC et al (2011) Restoration of ecosystem services and biodiversity: conflicts and opportunities. Trends Ecol Evol 26(10):541-549 
Cabral P, Levrel H, Viard F et al (2016) Ecosystem services assessment and compensation costs for installing seaweed farms. Mar Policy $71: 157-165$

Callaway JC, DeLaune RD, Patrick WH Jr (1997) Sediment accretion rates from four coastal wetlands along the Gulf of Mexico. Coast Res 3(1):181-191

Campbell AH, Marzinelli EM, Vergés A et al (2014) Towards restoration of missing underwater forests. PLoS One 9(1):e84106

Carpenter SR, Bennett EM, Peterson GD (2006) Scenarios for ecosystem services: an overview. Ecol Soc 11(1):29

Carpenter SR, Mooney HA, Agard J et al (2009) Science for managing ecosystem services: beyond the millennium ecosystem assessment. Proc Natl Acad Sci U S A 106(5):1305-1312

Castillo JM, Figueroa E (2009) Restoring salt marshes using small cordgrass, Spartinamaritima. Restor Ecol 17:324-326

Cole AJ, Mata L, Paul NA et al (2013) Using $\mathrm{CO}_{2}$ to enhance carbon capture and biomass applications of freshwater macroalgae. Glob Change Biol Bioenergy 6(6):637-645

Connell SD, Russell BD, Turner DJ et al (2008) Recovering a lost baseline: missing kelp forests from a metropolitan coast. Mar Ecol Prog Ser 360:63-72

Corlett RT, Wescott DA (2013) Will plants movement keeps up with climate change? Trends Ecol Evol 28(8):482-488

Costanza R, d'Arge R, De Groot R et al (1997) The value of the world's ecosystem services and natural capital. Nature 387:253-260

Costanza R, de Groot R, Sutton P et al (2014) Changes in the global value of ecosystem services. Glob Environ Change 26:152-158

Cox C, Valdivia A, McField M et al (2017) Establishment of marine protected areas alone does not restore coral reef communities in Belize. Mar Ecol Prog Ser 563:65-79

Cunha AH, Marbá NN, van Katwijk MM et al (2012) Changing paradigms in seagrass restoration. Restor Ecol 20(4):427-430

De Groot R, Brander L, Van Der Ploeg S et al (2012) Global estimates of the value of ecosystems and their services in monetary units. Ecosyst Serv 1(1):50-61

Doxa A, Albert CH, Leriche A et al (2017) Prioritizing conservation areas for coastal plant diversity under increasing urbanization. Environ Manag 201:425-434

Duke NC, Meynecke J-O, Dittman S et al (2007) A world without mangroves? Science 317(5834):41-42

EdwardsAJ, GomezED (2007) Reef restoration Concepts and Guidelines: making sensible management choices in the face of uncertainty. Coral Reef Targeted Research \& Capacity Building for Management Programme. St Lucia, Australia

Elliott M, Burdon D, Hemingway KL et al (2007) Estuarine, coastal and marine ecosystem restoration: confusing management and science: a revision of concepts. Estuar Coast Shelf Sci 74(3):349-366

Erwin KL (2009) Wetlands and global climate change: the role of wetland restoration in a changing world. Wetl Ecol Manag 17:71-84

Eyre BD, Cyronak T, Drupp P et al (2018) Coral reefs will transition to net dissolving end of century. Science 359(6378):908-911

Falace A, Zanelli E, Bressan G (2006) Algal transplantation as a potential tool for artificial reef management and environmental mitigation. Bull Mar Sci 78(1):161-166

Farley J, Costanza R (2010) Payments for ecosystem services: from local to global. Ecol Econ 69(11):2060-2068

Fonseca MS, Julius BE, Kenworthy WJ (2000) Integrating biology and economics in seagrass restoration: How much is enough and why? Ecol Eng 15(3-4):227-237

Fourqurean JW, Duarte CM, Kennedy H et al (2012) Seagrass ecosystems as a globally significant carbon stock. Nat Geosci 5(7):505-509

Fox HE, Mous PJ, Pet JS et al (2005) Experimental assessment of coral reef rehabilitation following blast fishing. Conserv Biol 19(1):98-107
Freedman RM, Espasandin C, Holcombe EF et al (2016) Using movements and habitat utilization as a functional metric of restoration for estuarine juvenile fish habitat. Mar Coast Fish 8(1):361-373

GanassinC, GibbsP (2008) A review of seagrass planting as a means of habitat compensation following loss of seagrass meadow. In: NSW Department of Primary Industries - Fisheries Final Report Series No. 96. NSW Department of Primary Industries, Cronulla Fisheries Research Centre of Excellence. Cronulla, Australia

Gedan KB, Kirwan ML, Wolanski E et al (2011) The present and future role of coastal wetland vegetation in protecting shorelines: answering recent challenges to the paradigm. Clim Chang 106(1):7-29

Giri C, Ochieng E, Tieszen L et al (2011) Status and distribution of mangrove forests of the world using Earth observation satellite data. Glob Ecol Biogeogr 20(1):154-159

Goforth HJ, Thomas J (1979) Plantings of red mangroves (Rhizophora mangle L.) for stabilization of Marl shorelines in the Florida Keys. In: Cole D (ed) Proceedings of the sixth annual conference on wetlands restoration and creation, 19 May 1979. Hillsborough Community College, Tampa

Grabowski JH, Brumbaugh RD, Conrad RF et al (2012) Economic valuation of ecosystem services provided by oyster reefs. Bioscience 62(10):900-909

Guerry AD, Ruckelshaus MH, Arkema KK et al (2012) Modeling benefits from nature: using ecosystem services to inform coastal and marine spatial planning. Int J Biodivers Sci Ecosyst Serv Manage $8(1-2): 107-121$

Guo Z, Li X, He Z et al (2018) Extremely low genetic diversity across mangrove taxa reflects past sea level changes and hints at poor future responses. Glob Chang Biol 24(4):1741-1748

Halpern BS, Walbridge S, Selkoe KA et al (2008) A global map of human impact on marine ecosystems. Science 319(5865):948-952

Harley CDG, Randall Hughes A, Hultgren KM et al (2006) The impacts of climate change in coastal marine systems. Ecol Lett 9(2):228-241

Harris JA, Hobbs RJ, Higgs E et al (2006) Ecological restoration and global climate change. Restor Ecol 14(2):170-176

Havens K, Vitt P, Still S et al (2015) Seed sourcing for restoration in an era of climate change. Nat Area J 35(1):122-133

Hein MY, Willis BL, Beeden R et al (2017) The need for broader ecological and socioeconomic tools to evaluate the effectiveness of coral restoration programs. Restor Ecol 25(6):873-883

Hemminga MA, Duarte CM (2000) Seagrass ecology. Cambridge University Press, Cambridge

Herkül K, Kotta J (2009) Effects of eelgrass (Zostera marina) canopy removal and sediment addition on sediment characteristics and benthic communities in the Northern Baltic Sea. Mar Ecol 30:74-82

Hill WG, Caballero A (1992) Artificial selection experiments. Annu Rev Ecol Syst 23:287-310

Himes-Cornell A, Pendleton L, Atiyah P (2018) Valuing ecosystem services from blue forests: a systematic review of the valuation of salt marshes, sea grass beds and mangrove forests. Ecosyst Serv 30:36-48

Hobbs RJ (2007) Setting effective and realistic restoration goals: key directions for research. Restor Ecol 15(2):354-357

Hobbs RJ, Harris JA (2001) Restoration ecology: repairing the earth's ecosystems in the new millennium. Restor Ecol 9(2):239-246

Hobbs RJ, Norton DA (1996) Towards a conceptual framework for restoration ecology. Restor Ecol 4(2):93-110

Hoegh-Guldberg O (1999) Climate change, coral bleaching and future of the world's coral reefs. Mar Freshw Res 50:839-866

Hoegh-Guldberg O, Bruno JF (2010) The impact of climate change on the world's marine ecosystems. Science 328(5985):1523-1528

Hoegh-Guldberg O, Mumby PJ, Hooten AJ et al (2007) Coral reefs under rapid climate change and ocean acidification. Science 318(5857):1737-1742 
Hoekstra JM, Boucher TM, Ricketts TH et al (2005) Confronting a biome crisis: global disparities of habitat loss and protection. Ecol Lett 8(1):23-29

IPCC (2014) Meyer LA, Pachauri, RK (eds) Synthesis report. Contribution of Working Groups I, II and III to the Fifth Assessment Report of the Intergovernmental Panel on Climate Change. IPCC, Geneva

Johnson M, Lustic C, Bartels E et al (2011) Caribbean Acropora restoration guide: best practices for propagation and population enhancement. The Nature Conservancy, Arlington

Kang CK, Choy EJ, Son Y et al (2008) Food web structure of a restored macroalgal bed in the eastern Korean peninsula determined by $\mathrm{C}$ and N stable isotope analyses. Mar Biol 153(6):1181-1198

KleypasJA, LangdonC (2006) coral reefs and changing seawater carbonate chemistry. In: Phinney JT, Hoegh-Guldberg O, Kleypas $\mathrm{J}$ et al (eds) Coral reefs and climate change: science and management, vol 61. American Geophysical Union, pp 73-110

Koch M, Bowes G, Ross C et al (2012) Climate change and ocean acidification effects on seagrasses and marine macroalgae. Glob Chang Biol 19(1):103-132

La Peyre M, Furlong J, Brown LA et al (2014) Oyster reef restoration in the Northern Gulf of Mexico: extent, methods and outcomes. Ocean Coast Manag 89:20-28

Ledig FT, Kitzmiller JH (1992) Genetic strategies for reforestation in the face of global climate change. For Ecol Manag 50(1-2):153-169

Lee JH, Sidharthan M, Jung SM et al (2008) Comparison of the effectiveness of four organic chemoattractants towards zoospores of Ulva pertusa and macrofouling. J Environ Biol 29:621-627

Lindahl U (1998) Low-tech rehabilitation of degraded coral reefs through transplantation of stag-horn coral. Ambio 27:645-650

Liquete C, Piroddi C, Drakou EG et al (2013) Current status and future prospects for the assessment of marine and coastal ecosystem services: a systematic review. PLoS One 8(7):e67737

Locatelli T, Binet T, Kairo JG et al (2014) Turning the tide: how blue carbon and payments for ecosystem services (PES) might help save mangrove forests. Ambio 43(8):981-995

Lotze HK, Lenihan HS, Bourque BJ et al (2006) Depletion, degradation, and recovery potential of estuaries and coastal seas. Science 312(5781):1806-1809

Lovelock CE, Feller IC, McKee KL et al (2005) Variation in mangrove forest structure and sediment characteristics in Bocas del Toro, Panama. Caribb J Sci 41(3):456-464

Martínez-Alier J (2014) Theenvironmentalism of the poor. Geoforum $54: 239-241$

McDonald T, Gann G, Jonson J et al (2016) International standards for the practice of ecological restoration-including principles and key concepts. Society for Ecological Restoration, Washington, DC

McLeod E, Chmura GL, Bouillon S et al (2011) A blueprint for blue carbon: toward an improved understanding of the role of vegetated coastal habitats in sequestering $\mathrm{CO}_{2}$. Front Ecol Environ 9(10):552-560

MEA (2005) Millennium ecosystem assessment. World Resources Institute, Washington DC

Mendelsohn R, Olmstead S (2009) The economic valuation of environmental amenities and disamenities: methods and applications. Annu Rev Environ Resour 34:325-347

Micheli F, Halpern BS, Walbridge S et al (2013) Cumulative human impacts on Mediterranean and Black Sea marine ecosystems: assessing current pressures and opportunities. PLoS One 8(12):e79889

Moberg F, Folke C (1999) Ecological goods and services of coral reefs ecosystems. Ecol Econ 29:215-233

Muradian R, Rival L (2012) Between markets and hierarchies: the challenge of governing ecosystem services. Ecosyst Serv 1(1):93-100
Muradian R, Corbera E, Pascual U et al (2010) Reconciling theory and practice: an alternative conceptual framework for understanding payments for environmental services. Ecol Econ 69(6):1202-1208

Nelleman C, Corcoran E, Duarte CM et al (2009) Blue carbon: a rapid response assessment. United Nations Environment Programme, GRID-Arendal

NOAA (1997) National oceanic and atmospheric administration, Damage Assessment and Restoration Program. Habitat equivalency analysis: an overview. Policy and Technical Paper Series 95(1)

Norlund L, Jackson EL, Nakaoka M et al (2018) Seagrass ecosystem services -- What's next? Mar Pollut Bull 134:145-151

Novacek MJ, Cleland EE (2001) The current biodiversity extinction event: scenarios for mitigation and recovery. Proc Natl Acad Sci 98(10):5466-5470

Nyström M, Norström AV, Blenckner T et al (2012) Confronting feedbacks of degraded marine ecosystems. Ecosystems 15(5):695-710

O'Leary JK, Micheli F, Airoldi L et al (2017) The resilience of marine ecosystems to climatic disturbances. Bioscience 67(3):208-220

Ow YX, Collier CJ, Uthicke S (2015) Responses of three tropical seagrass species to $\mathrm{CO}_{2}$ enrichment. Mar Biol 162(5):1005-1017

Palacios SL, Zimmerman RC (2007) Response of eelgrass Zostera marina to $\mathrm{CO}_{2}$ enrichment: possible impacts of climate change and potential for remediation of coastal habitats. Mar Ecol Prog Ser 344:1-13

Paling EI, Fonseca M, van Katwijk MM et al (2009) Chapter 24: Seagrass restoration. In: Perillo W, Wolanski E, Brinson C et al (eds) Coastal wetlands: an integrated ecosystem approach, 1st edn. Elservier, Amsterdam, pp 687-713

Palmer MA, Ambrose RF, Poff NL (1997) Ecological theory and community restoration ecology. Restor Ecol 5(4):291-300

Pandolfi JM, Bradbury RH, Sala E et al (2003) Global trajectories of the long-term decline of coral reef ecosystems. Science 301(5635):955-958

Perkol-Finkel S, Airoldi L (2010) Loss and recovery potential of marine habitats: an experimental study of factors maintaining resilience in subtidal algal forests at the Adriatic sea. PLoS One 5(5):e10791

Perkol-Finkel S, Ferrario F, Nicotera V et al (2012) Conservation challenges in urban seascapes: promoting the growth of threatened species on coastal infrastructures. J Appl Ecol 49(6):1457-1466

Perrow MR, Davy AJ (2002) Handbook of ecological restoration, vol 2. Cambridge University Press, Cambridge

Peterson CH, Kneib RT, Manen CA (2003) Scaling restoration actions in the marine environment to meet quantitative targets of enhanced ecosystem services. Mar Ecol Prog Ser 264:73-176

PizarroV, CarrilloV, García-RuedaA(2012) Growing corals in line and floating nurseries at Tayrona Park. Abstracts of the 12th International Coral Reef Symposium, 2012, Cairns

Powers SP, Boyer KE (2014) Marine restoration ecology. In: Bertness MD, Bruno JP, Silliman BR, Stachowicz JJ (eds) Marine community ecology and conservation. Sinauer Publishing, Sunderland, pp 495-516

Powers S, Peterson C, Grabowski J et al (2009) Success of constructed oyster reefs in no-harvest sanctuaries: implications for restoration. Mar Ecol Prog Ser 389:159-170

Primavera J, Esteban J (2008) A review of mangrove rehabilitation in the Philippines: successes, failures and future prospects. Wetl Ecol Manag 16:345-358

Proffitt CE, Devlin DJ (2005) Long-term growth and succession in restored and natural mangrove forests in southwestern Florida. Wetl Ecol Manag 13:531-551

Redford KH, Adams WM (2009) Payment for ecosystem services and the challenge of saving nature. Conserv Biol 23(4):785-787 
Reynolds LK, Waycott M, McGlathery KJ et al (2016) Ecosystem services returned through seagrass restoration. Restor Ecol 24(5):583-588

Richards DR, Friess DA (2017) Characterizing Coastal Ecosystem Service Trade-offs with Future Urban Development in a Tropical City. Environ Manag 60(5):961-973

Rico L, Ogaya R, Barbeta A et al (2013) Changes in DNA methylation fingerprint of Quercus ilex trees in response to experimental field drought simulating projected climate change. Plant Biol 16(2):419-427

Rinkevich B (2005) Conservation of coral reefs through active restoration measures: recent approaches and last decade progress. Environ Sci Technol 39(12):4333-4342

Robertson AI, Duke NC (1987) Mangroves as nursery sites: comparisons of the abundance and species composition of fish and crustaceans in mangroves and other nearshore habitats in tropical Australia. Mar Biol 96(2):193-205

Rodríguez FVL (2018) Mangrove concessions: an innovative strategy for community mangrove conservation in ecuador. In: Makowski C, Finkl CW (eds) Threats to mangrove forests, Hazards. Vulnerability and Management. Springer, Cham, pp 557-578

Rönnbäck P, Crona B, Ingwall L (2007) The return of ecosystem goods and services in replanted mangrove forests: perspectives from local communities in Kenya. Environ Conserv 34(4):313-324

Rossi-Snook K, Ozbay G, Marenghi F (2010) Oyster (Crassostreavirginica) gardening program for restoration in Delaware's Inland Bays, USA. AquacInt 18:61-67

Ruiz-Jaen MC, AideTM (2005) Restoration success: how is it being measured? Restor Ecol 13(3):569-577

Russell M, Greening H (2015) Estimating benefits in a recovering estuary: Tampa Bay, Florida. Estuar Coasts 38(1):9-18

Sala E (2004) The past and present topology and structure of Mediterranean subtidal rocky-shore food webs. Ecosystems 7:333-340

Salomidi M, Katsanevakis S, Borja Á et al (2012) Assessment of goods and services, vulnerability, and conservation status of European seabed biotopes: a stepping stone towards ecosystem-based marine spatial management. Medit Mar Sci 13(1):49-88

Salomon M, Dahms H (2018) Marine Ecosystem Services. In: Salomon M, Markus T (eds) Handbook on Marine environment protection. Springer, Cham, pp 67-75

Scapin L, Zucchetta M, Facca C et al (2016) Using fish assemblage to identify success criteria for seagrass habitat restoration. Web Ecol 16(1):33-36

Scheffer M, Carpenter S, Foley JA et al (2001) Catastrophic shifts in ecosystems. Nature 413:591-596

Schröter M, van der Zanden EH, van Oudenhoven AP (2014) Ecosystem services as a contested concept: a synthesis of critique and counterarguments. Conserv Lett 7(6):514-523

Seaman W (2007) Artificial habitats and the restoration of degraded marine ecosystems and fisheries. Hydrobiologia 580(1):143-155

SER (1998) The SER primer on ecological restoration.Society for Ecological Restoration, Science \& Policy Working Group, Tucson

Shackelford N, Hobbs RJ, Burgar JM et al (2013) Primed for change: developing ecological restoration for the 21st century. Restor Ecol 21(3):297-304

Shaish L, Levy G, Gomez ED et al (2008) Fixed and suspended coral nurseries in the Philippines: establishing the first step in the "gardening concept" of reef restoration. J Exp Mar Biol Ecol 358:86-97

Silliman BR, Schrack E, He Q et al (2015) Facilitation shifts paradigms and can amplify coastal restoration efforts. Proc Natl Acad Sci 112(46):14295-14300

Speers AE, Besedin EY, Palardy JE et al (2016) Impacts of climate change and ocean acidification on coral reef fisheries: an integrated ecological-economic model. Ecol Econ 128:33-43
Staszak LA, Armitage AR (2012) Evaluating salt marsh restoration success with an index of ecosystem integrity. J Coast Res 29(2):410-418

Steneck RS, Graham MH, Bourque BJ et al (2002) Kelp forest ecosystems: biodiversity, stability, resilience and future. Environ Conserv 29(4):436-459

Suding KN (2011) Toward an era of restoration in ecology: successes, failures, and opportunities ahead. Annu Rev EcolEvolSyst 42:465-487

Swan KD, McPherson JM, Seddon PJ et al (2016) Managing marine biodiversity: the rising diversity and prevalence of marine conservation translocations. Conserv Lett 9(4):239-251

Tallis H, Polasky S (2009) Mapping and valuing ecosystem services as an approach for conservation and natural-resource management. Ann N Y Acad Sci 1162(1):265-283

Terawaki T, Hasegawa H, Arai S et al (2001) Management-free techniques for restoration of Eisenia and Ecklonia beds along the central Pacific coast of Japan. J Appl Phycol 13(1):13-17

Terawaki T, Yoshikawa K, Yoshida G et al (2003) Ecology and restoration techniques for Sargassum beds in the Seto Inland Sea, Japan. Mar Pollut Bull 47(1-6):198-201

Thorhaug A, Poulos HM, López-Portillo J et al (2017) Seagrass blue carbon dynamics in the Gulf of Mexico: stocks, losses from anthropogenic disturbance, and gains through seagrass restoration. Sci Total Environ 605:626-636

Torda G, Donelson JM, Aranda M et al (2017) Rapid adaptive responses to climate change in corals. Nat Clim Chang 7:627-636

Tortolero-Langarica JJA, Cupul-Magaña AL, Rodríguez-Troncoso AP (2014) Restoration of a degraded coral reef using a natural remediation process: a case study from a Central Mexican Pacific National Park. Ocean Coast Manag 96:12-19

Tsihrintzis VA (1970) Protection of wetlands from development impacts. WIT Trans Ecol Environ 34

UNEPand CIFOR (2014) Guiding principles for delivering coastal wetland carbon projects. United Nations Environment Programme, Nairobi Kenya and Center for International Forestry Research, Bogor

Valiela I, Bowen JL, York JK (2001) Mangrove forests: one of the world's threatened major tropical environments. Bioscience 51(10):807-815

Van Katwijk MM, Thorhaug A, Marbà N et al (2016) Global analysis of seagrass restoration: the importance of large-scale planting. J Appl Ecol 53(2):567-578

Van Oppen MJH, Oliver JK, Putnam HM et al (2015) Building coral reef resilience through assisted evolution. Proc Natl Acad Sci 112(8):2307-2313

Van Oppen MJH, Gates RD, Blackall LL et al (2017) Shifting paradigms in restoration of the world's coral reefs. Glob Chang Biol 23(9):3437-3448

Veron JEN, Hoegh-Guldberg O, Lenton TM et al (2009) The coral reef crisis: the critical importance of $<350 \mathrm{ppm} \mathrm{CO}_{2}$. Mar Pollut Bull 58:1428-1436

Waycott M, Duarte CM, Carruthers TJ et al (2009) Accelerating loss of seagrasses across the globe threatens coastal ecosystems. Proc Natl Acad Sci 106(30):12377-12381

Worm B, Barbier EB, Beaumont N et al (2006) Impacts of biodiversity loss on ocean ecosystem services. Science 314(5800):787-790

Wylie L, Sutton-Grier AE, Moore A (2016) Keys to successful blue carbon projects: lessons learned from global case studies. Mar Policy 65:76-84

Xu S, He Z, Zhang Z et al (2017) The origin, diversification and adaptation of a major mangrove clade (Rhizophorae) revealed by wholegenome sequencing. Natl Sci Rev 4(5):721-734

Yoon JT, Sun SM, Chung G (2014) Sargassum bed restoration by transplantation of germlings grown under protective mesh cage. J Appl Phycol 26(1):505-509 
Young TP (2000) Restoration ecology and conservation biology. Biol Conserv 92(1):73-83

Yu YQ, Zhang QS, Tang YZ et al (2012) Establishment of intertidal seaweed beds of Sargassumthunbergii through habitat creation and germling seeding. Ecol Eng 44:10-17

ZarnochCB, SchreibmanMP (2012) Growth and reproduction of eastern oysters, Crassostreavirginica, in a New York City estuary: implications for restoration. In: Volume seven. Urban Habitats. Available via: www.urbanhabitats.org/v07n01/easternoysters_full. html. Accessed 12 April 2017
Zedler J, Morzaria-Luna H, Ward K (2003) The challenge of restoring vegetation on tidal, hypersaline substrates. Plant Soil 253:259-273

Zhang YS, Cioffi WR, Cope R et al (2018) Aglobal synthesis reveals gaps in coastal habitat restoration research. Sustainability 10:1040

Zhao Q, Bai J, Huang L et al (2016) A review of methodologies and success indicators for coastal wetland restoration. Ecol Indic $60: 442-452$

Zimmerman RC, Hill VJ, Jinuntuya M et al (2017) Experimental impacts of climate warming and ocean carbonation on eelgrass Zostera marina. Mar Ecol Prog Ser 566:1-15

Open Access This chapter is licensed under the terms of the Creative Commons Attribution 4.0 International License (http://creativecommons. $\mathrm{org} /$ licenses/by/4.0/), which permits use, sharing, adaptation, distribution and reproduction in any medium or format, as long as you give appropriate credit to the original author(s) and the source, provide a link to the Creative Commons license and indicate if changes were made.

The images or other third party material in this chapter are included in the chapter's Creative Commons license, unless indicated otherwise in a credit line to the material. If material is not included in the chapter's Creative Commons license and your intended use is not permitted by statutory regulation or exceeds the permitted use, you will need to obtain permission directly from the copyright holder. 